\title{
Nitrogen isotopic composition of plants and soil in an arid mountainous terrain: south slope versus north slope
}

\author{
Chongjuan Chen ${ }^{1}$, Yufu Jia ${ }^{1}$, Yuzhen Chen ${ }^{1}$, Imran Mehmood ${ }^{2}$, Yunting Fang ${ }^{3}$, and Guoan Wang ${ }^{1}$ \\ ${ }^{1}$ Beijing Key Laboratory of Farmland Soil Pollution Prevention-control and Remediation, Department of Environmental \\ Sciences and Engineering, College of Resources and Environmental Sciences, China Agricultural University, \\ Beijing, 100193, China \\ ${ }^{2}$ Key Laboratory of Plant-Soil Interactions, MOE, Department of Plant Nutrition, College of Resources and Environmental \\ Sciences, China Agricultural University, Beijing, 100193, China \\ ${ }^{3}$ CAS Key Laboratory of Forest Ecology and Management, Institute of Applied Ecology, Chinese Academy of Sciences, \\ Shenyang, 110164, China
}

Correspondence: Guoan Wang (gawang@cau.edu.cn)

Received: 20 July 2017 - Discussion started: 4 September 2017

Revised: 23 November 2017 - Accepted: 4 December 2017 - Published: 17 January 2018

\begin{abstract}
Nitrogen cycling is tightly associated with environment. The south slope of a given mountain could significantly differ from north slope in environment. Thus, N cycling should also be different between the two slopes. Since leaf $\delta^{15} \mathrm{~N}$, soil $\delta^{15} \mathrm{~N}$ and $\Delta \delta^{15} \mathrm{~N}_{\text {leaf-soil }}\left(\Delta \delta^{15} \mathrm{~N}_{\text {leaf-soil }}=\right.$ leaf $\delta^{15} \mathrm{~N}-$ soil $\delta^{15} \mathrm{~N}$ ) could reflect the $\mathrm{N}$ cycling characteristics, we put forward a hypothesis that leaf $\delta^{15} \mathrm{~N}$, soil $\delta^{15} \mathrm{~N}$ and $\Delta \delta^{15} \mathrm{~N}_{\text {leaf-soil }}$ should differ between the two slopes. However, such a comparative study between two slopes has never been conducted. In addition, environmental effects on leaf and soil $\delta^{15} \mathrm{~N}$ derived from studies at global scale were often found to be different from those on a regional scale. This led to our argument that environmental effects on leaf and soil $\delta^{15} \mathrm{~N}$ could depend on local environment. To confirm our hypothesis and argument, we measured leaf and soil $\delta^{15} \mathrm{~N}$ on the south and north slopes of Tian Shan. Remarkable environmental differences between the two slopes provided an ideal opportunity for our test. The study showed that leaf $\delta^{15} \mathrm{~N}$, soil $\delta^{15} \mathrm{~N}$ and $\delta^{15} \mathrm{~N}_{\text {leaf-soil }}$ on the south slope were greater than those on the north slope, although the difference in soil $\delta^{15} \mathrm{~N}$ was not significant. The result confirmed our hypothesis and suggested that the south slope has higher soil $\mathrm{N}$ transformation rates and soil $\mathrm{N}$ availability than the north slope. In addition, in this study it was observed that the significant influential factors of leaf $\delta^{15} \mathrm{~N}$ were temperature, precipitation, leaf $\mathrm{N}$, leaf $\mathrm{C} / \mathrm{N}$, soil moisture and silt / clay ratio on the north slope, whereas on the south slope only leaf $\mathrm{C} / \mathrm{N}$ was related
\end{abstract}

to leaf $\delta^{15} \mathrm{~N}$. The significant influential factors of soil $\delta^{15} \mathrm{~N}$ were temperature, precipitation, soil moisture and silt / clay ratio on the north slope, whereas on the south slope, mean annual precipitation and soil moisture exerted significant effects. Precipitation exerted contrary effects on soil $\delta^{15} \mathrm{~N}$ between the two slopes. Thus, this study supported our argument that the relationships between leaf and soil $\delta^{15} \mathrm{~N}$ and environmental factors are localized.

\section{Introduction}

In a natural terrestrial ecosystem, nitrogen $(\mathrm{N})$ is not only the most required element but is also usually a key limiting resource for plants (Vitousek et al., 1997); thus, studying $\mathrm{N}$ cycling is of vital importance. The variations in nitrogen isotope ratio $\left(\delta^{15} \mathrm{~N}\right)$ in plants and soil are tightly associated with many biogeochemical processes, including $\mathrm{N}$ mineralization, ammonia volatilization, nitrification and denitrification (Högberg, 1997; Houlton et al., 2006). Mineralization produces available $\mathrm{N}$, including ammonium and nitrate, which are the substrates for ammonia volatilization, nitrification and denitrification. During these processes, gaseous $\mathrm{N}$ loss is more likely to be depleted in ${ }^{15} \mathrm{~N}$, which will cause the remaining $\mathrm{N}$ pool and subsequent plants to enrich ${ }^{15} \mathrm{~N}$ (Högberg, 1997). Additionally, the difference between leaf $\delta^{15} \mathrm{~N}$ and soil $\delta^{15} \mathrm{~N}\left(\delta^{15} \mathrm{~N}_{\text {leaf-soil }}=\right.$ leaf $\delta^{15} \mathrm{~N}-$ soil $\left.\delta^{15} \mathrm{~N}\right)$, which is 
also named enrichment factor (Emmett et al., 1998), was also suggested to be an indicator of ecosystem $\mathrm{N}$ cycling (Charles and Garten, 1993; Kahmen et al., 2008; Fang et al., 2011), and it was also reported to be correlated with soil $\mathrm{N}$ transformation rates $(\mathrm{N}$ mineralization or nitrification rates; Garten and Van Miegroet, 1994). Thus, nitrogen isotopes have been widely applied in studies of terrestrial ecosystem $\mathrm{N}$ cycling (Handley et al., 1999; Evans, 2001; Robinson, 2001; Hobbie and Colpaert, 2003; Houlton et al., 2007).

For a given mountain, its south slope may be significantly different from its north slope in climate and environment. It is well known that ecosystem $\mathrm{N}$ cycling is associated with climatic and environmental conditions (Amundson et al., 2003; Craine et al., 2009; Yang et al., 2013; Zhou et al., 2016); thus, ecosystem $\mathrm{N}$ cycling should vary across south and north slopes. Since leaf $\delta^{15} \mathrm{~N}$, soil $\delta^{15} \mathrm{~N}$ and $\delta^{15} \mathrm{~N}_{\text {leaf-soil }}$ could reflect and indicate ecosystem $\mathrm{N}$ cycling, differences in leaf $\delta^{15} \mathrm{~N}$, soil $\delta^{15} \mathrm{~N}$ and $\delta^{15} \mathrm{~N}_{\text {leaf-soil }}$ were expected to appear between south and north slopes. Comparisons of leaf $\delta^{15} \mathrm{~N}$, soil $\delta^{15} \mathrm{~N}$ and $\delta^{15} \mathrm{~N}_{\text {leaf-soil }}$ across two slopes of a mountain would provide a good insight into the response of terrestrial ecosystem $\mathrm{N}$ cycling to climate and environment. However, to our knowledge, such a comparative study has never been conducted.

Most of the published works consistently suggest that leaf $\delta^{15} \mathrm{~N}$ increases with increasing mean annual temperature (MAT) and decreasing mean annual precipitation (MAP) on large regional or global scales (Austin and Sala, 1999; Amundson et al., 2003; Craine et al., 2009). However, in contrast to the commonly reported patterns, leaf $\delta^{15} \mathrm{~N}$ was found to be negatively related to MAT in some Asian regions, e.g., in Inner Mongolia (Cheng et al., 2009) and eastern China (Sheng et al., 2014). Relative to plant $\delta^{15} \mathrm{~N}$, soil $\delta^{15} \mathrm{~N}$ has been little addressed. Some studies demonstrated that soil $\delta^{15} \mathrm{~N}$ decreased with increasing MAP and decreasing MAT on a global scale (Amundson et al., 2003; Craine et al., 2015b). However, studies based on local or regional scales showed inconsistent results with the global patterns. Cheng et al. (2009) reported that soil $\delta^{15} \mathrm{~N}$ increased with decreasing MAT in Inner Mongolia. Sheng et al. (2014) showed that the soil $\delta^{15} \mathrm{~N}$ in tropical forest ecosystems were more ${ }^{15} \mathrm{~N}$ depleted than in temperate forest ecosystems of eastern China. Yang et al. (2013) found that soil $\delta^{15} \mathrm{~N}$ did not vary with either MAT or MAP on the Tibetan Plateau. Wang et al. (2014) revealed a second-order polynomial relationship between soil $\delta^{15} \mathrm{~N}$ and aridity index across arid and semiarid regions. The inconsistent observations above led to our argument that the relationships between environmental factors and leaf $\delta^{15} \mathrm{~N}$ or soil $\delta^{15} \mathrm{~N}$ would depend on local environment. Comparisons of the effects of climatic and environmental factors on leaf $\delta^{15} \mathrm{~N}$ and soil $\delta^{15} \mathrm{~N}$ between the south and north slopes of a given mountain could test the argument.

This study was conducted on the south slope and the north slope of Tian Shan. It is an ideal place for testing our hypothesis because its south slope differs greatly from its north
Table 1. Climate data from the meteorological observatories in the research area.

\begin{tabular}{llrrr}
\hline $\begin{array}{l}\text { Meteorological } \\
\text { observatories }\end{array}$ & Locations & $\begin{array}{r}\text { MAT } \\
{ }^{\circ} \mathrm{C}\end{array}$ & $\begin{array}{r}\text { MAP } \\
\mathrm{mm}\end{array}$ & $\begin{array}{r}\text { Alt. } \\
\mathrm{m}\end{array}$ \\
\hline WLMQ & North slope & 6.9 & 269.4 & 918.7 \\
MOS & North slope & -5.2 & 453.4 & 3539.0 \\
BLT & South slope & 6.6 & 208.4 & 1738.3 \\
YQ & South slope & 8.4 & 73.3 & 1055.8 \\
\hline
\end{tabular}

Abbreviation: WLMQ: Urumchi meteorological observatory; MOS: mountain observation station of the Tian Shan Glaciological Station, Chinese Academy of Sciences; BLT: Baluntai meteorological observatory; YQ: Yanqi meteorological observatory; MAT: annual mean temperature; MAP: annual mean precipitation.

slope in climatic and environmental conditions (Deng et al., 2015; Zhang et al., 2016). The first objective of the present study was to confirm our hypothesis that the south slope differs from the north slope in leaf $\delta^{15} \mathrm{~N}$, soil $\delta^{15} \mathrm{~N}$ and $\delta^{15} \mathrm{~N}_{\text {leaf-soil. }}$. The second objective was to test our argument that environmental effects on leaf $\delta^{15} \mathrm{~N}$ and soil $\delta^{15} \mathrm{~N}$ are localized.

\section{Materials and methods}

\subsection{Study area}

Tian Shan is one of the seven largest mountain ranges in the world. It has a total length of $2500 \mathrm{~km}$ straddling four countries including China, Kazakhstan, Kyrgyzstan and Uzbekistan. In China, Tian Shan stretches $1700 \mathrm{~km}$ along the eastwest direction in the Xinjiang Uygur Autonomous Region, covers about $570000 \mathrm{~km}^{2}$ and accounts for one-third of the whole area. Tian Shan divides Xinjiang into two parts; the south of Tian Shan is the Tarim Basin and the north is the Dzungarian Basin.

This study was conducted along an elevation transect on the north and south slopes on eastern Tian Shan (42.43$43.53^{\circ} \mathrm{N}, 86.23-87.32^{\circ}$ E; Fig. 1). Tian Shan is characterized by an arid mountainous climate; vertical variations in temperature and precipitation are very pronounced; temperature decreases and precipitation increases with altitude on both slopes. The north slope differs significantly from the south slope both in climate and vegetation. On the north slope, the MAT ranges from -6.40 to $3.90^{\circ}$ with the average temperature of $-1.85^{\circ}$, and the MAP ranges from 314 to $472 \mathrm{~mm}$ with an average precipitation of $402 \mathrm{~mm}$. On the south slope, the MAT varies from -5.65 to $9.23^{\circ}$ with an average temperature of $1.03^{\circ}$, and the MAP varies from 124 to $308 \mathrm{~mm}$ with an average precipitation of $246 \mathrm{~mm}$. There were four meteorological observatories along our elevation transects, two on either slope of Tian Shan (Table 1).

Intact and continuous vertical vegetation and soil spectrums can be observed along the two slopes. On the north slope from bottom to top, the vegetation spectrum 


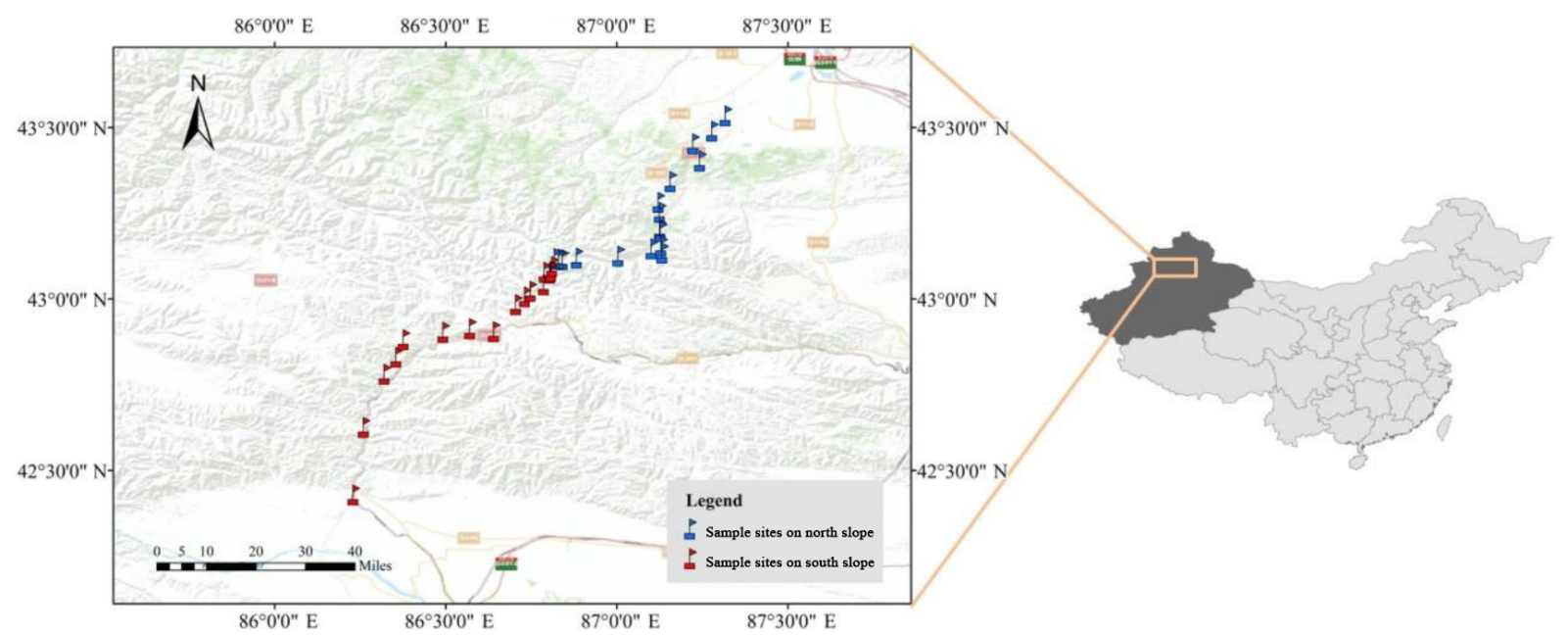

Figure 1. Sketch of study area. Locations of the sampling sites are indicated with points. A total of 17 sites (blue dots) were selected on the north slope, and 16 sites (red dots) were selected on the south slope.

consists of upland desert $(800-1100 \mathrm{~m})$, upland steppe (1100-2500 m), frigid coniferous forest (1800-2700 m), subalpine meadow $(2500-3300 \mathrm{~m})$, alpine meadow (3000$3700 \mathrm{~m}$ ), alpine sparse vegetation and a desert zone (3700$3900 \mathrm{~m})$, and an alpine ice and snow zone $(>3900 \mathrm{~m})$. The main species on the north slope included Kobresia myosuroides, Carex enervis, Poa annua and Thalictrum aquilegifolium. A corresponding soil spectrum on the north slope includes brown calcic soil (800-1100 m), chestnut soil $(1100-2500 \mathrm{~m})$, mountain grey cinnamon forest soil (1800-2700 m), subalpine meadow soil (2500-3300 m), alpine meadow soil $(3000-3700 \mathrm{~m})$ and chilly desert soil $(>3700 \mathrm{~m})$. While on the south slope, it includes upland desert (1300-1800 m), arid upland steppe (1800-2600 m), subalpine steppe (2600-2800 m), alpine meadow and cushion plants $(2800-3800 \mathrm{~m})$, an alpine desert zone (3800$4000 \mathrm{~m})$, and an alpine ice and snow zone $(>4000 \mathrm{~m})$. The main species occurring on the south slope were Ephedra sinica, Stipa grandis, Stipa capillata, Achnatherum splendens, Nitraria tangutorum, Caragana sinica and Suaeda glauca. The corresponding soil spectrum of the south slope consists of sierozem $(1300-1800 \mathrm{~m})$, chestnut soil (1800$2800 \mathrm{~m})$, alpine meadow soil $(2800-3800 \mathrm{~m})$ and chilly desert soil $(>3800 \mathrm{~m})$.

\subsection{Plants and soil sampling}

An altitudinal transect of 1564 to $3800 \mathrm{~m}$ above sea level (a.s.l.) was set on the north slope, and 1300 to $3780 \mathrm{~m}$ a.s.l. was set on the south slope. A few human habitats are distributed along the two transects. Plant and soil samples were collected in July of 2014. To minimize the influences of human activities, light regime or location within the canopy, the sampling was restricted to open sites that are far from the major roads and human habitats.
Plants and soil were collected along the two transects at altitudinal intervals of about $100 \mathrm{~m}$. Almost all plant species that we found at each sampling site were collected, and at each site five to seven individual plants of each species were collected and the same number of leaves were sampled from each individual plant. For shrubs and herbs, the uppermost leaves of each individual plant were collected; for tree species, eight leaves were collected from each individual, two leaves were collected at each of the four cardinal directions from the positions of full irradiance, about $8-10 \mathrm{~m}$ above the ground. The leaves from the same species of each site were combined into one sample. Excluding Nfixing plants and mosses, a total of 90 plant samples were collected from the north slope, including 72 herbs and 18 woody plants, and 105 were collected on the south slope, covering 85 herbs and 20 woody plants.

Surface soils $(0-5 \mathrm{~cm})$ were collected after removing the litter layer at each sampling site. At each location, one composite soil sample was prepared by combining six randomly taken subsamples within a radius of $20 \mathrm{~m}$. The sample was used to determine soil index, including $\delta^{15} \mathrm{~N}, \mathrm{~N}$ content, silt / clay ratio, $\mathrm{pH}$ and particle size. In addition, at each sampling site, we also collected another three soil samples using a ring, which were used to measure soil bulk density and moisture.

\subsection{Laboratory measurements}

Plant and soil samples were air-dried in the field and then in the laboratory. The soil samples were sieved through a $2 \mathrm{~mm}$ sieve to remove stones and plant residues. Plant leaves and about $5 \mathrm{~g}$ of sieved soil samples were then ground into a fine powder using a steel ball mixer mill MM200 (Retsch GmbH, Haan, Germany). $\delta^{15} \mathrm{~N}, \mathrm{~N}$ and $\mathrm{C}$ contents in leaves and $\delta^{15} \mathrm{~N}$ and $\mathrm{N}$ contents in soil were measured on a Delta ${ }^{\text {Plus }} \mathrm{XP}$ mass 
spectrometer (Thermo Scientific, Bremen, Germany) coupled with an automated elemental analyzer (Flash EA1112, CE Instruments, Wigan, UK) in continuous flow mode at the Stable Isotope Laboratory of the College of Resources and Environmental Sciences, China Agricultural University. For this measurement, we obtained standard deviations of less than $0.1 \%$ for $\mathrm{C}$ and $\mathrm{N}$ contents and less than $0.15 \%$ o for $\delta^{15} \mathrm{~N}$ among replicates of the same sample.

The measurements of soil $\mathrm{pH}$ and soil particle size (clay, silt and sand content) were determined using the sieved soil samples. Soil $\mathrm{pH}$ was measured using the $\mathrm{pH}$ electrode in soil water suspension, with a soil-to-water ratio of $1: 2.5(10 \mathrm{~g}$ soil and $25 \mathrm{~mL}$ deionized water removing carbon dioxide). Soil particle size (clay, silt and sand content) was analyzed using a particle size analyzer (Malvern Masterizer 2000, UK) after removing the calcium carbonates and organic matter. Soil moisture and bulk density were determined after ovendrying at $105 \pm 2^{\circ}$ to a constant weight. Soil moisture of each sample was the difference between its wet and dry weight divided by its dry weight. Soil bulk density was the dry weight divided by the certain volume of the ring knife.

\subsection{Statistical analysis}

The MAT and MAP data of each sampling elevation used in the statistical analyses were generated through interpolation based on the climatic data derived from the four meteorological observatories distributed along the altitudinal transect. Statistical analyses were conducted using SPSS software (SPSS for Windows, version 20.0; Chicago, IL, USA). One-way ANOVA was used to compare leaf $\delta^{15} \mathrm{~N}$, soil $\delta^{15} \mathrm{~N}$ and $\delta{ }^{15} \mathrm{~N}_{\text {leaf-soil }}$ between the north and south slopes. Leaf $\mathrm{C} / \mathrm{N}$ was $\mathrm{ln}$-transformed to improve data normality. The relationships between $\delta^{15} \mathrm{~N}_{\text {leaf-soil }}$ and leaf $\delta^{15} \mathrm{~N}$ were performed with the linear regression on the two slopes. Leaf and soil $\delta^{15} \mathrm{~N}$ were first analyzed using multiple linear regressions against all potential influential factors using ordinary least-square (OLS) estimation. The potential influential factors of leaf $\delta^{15} \mathrm{~N}$ included MAP, MAT, leaf $\mathrm{N}$ content, leaf $\mathrm{C} / \mathrm{N}$, soil $\delta^{15} \mathrm{~N}$, soil $\mathrm{N}$ content, silt / clay ratio, soil moisture, soil bulk density and soil $\mathrm{pH}$. The potential influential factors of soil $\delta^{15} \mathrm{~N}$ consisted of MAP, MAT, soil N content, silt / clay ratio, soil moisture and bulk density, and soil $\mathrm{pH}$. Finally, both principal component analysis (PCA) and correlation analysis were conducted to explore the complicated relationship among these factors and leaf or soil $\delta^{15} \mathrm{~N}$.

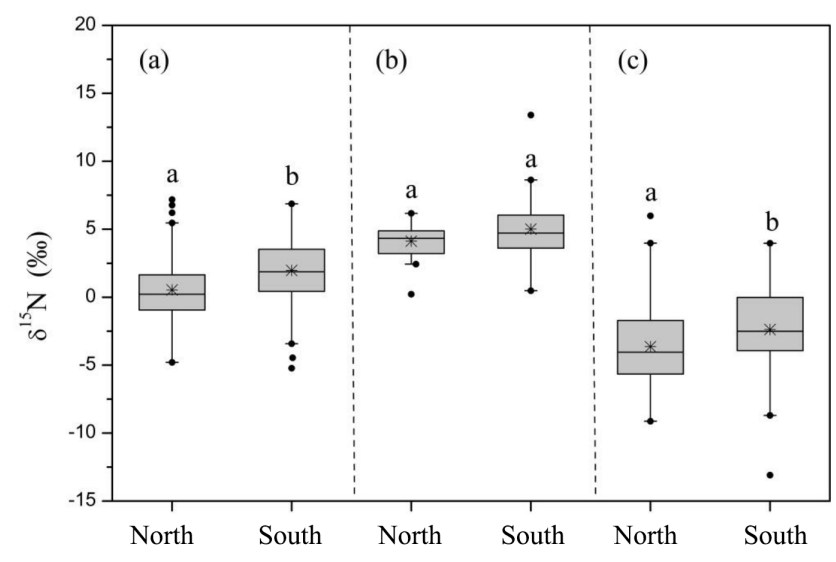

Figure 2. Differences in (a) leaf $\delta^{15} \mathrm{~N}$, (b) soil $\delta^{15} \mathrm{~N}$ and (c) $\delta{ }^{15} \mathrm{~N}_{\text {leaf-soil }}$ between the north and south slopes of Tian Shan.Each box represents the range of the middle $50 \%$ of group values; the center lines and points within the boxes are the median and mean values. Whiskers represent the 25 and $75 \%$ percentiles, and outliers are plotted as dots outside this range.
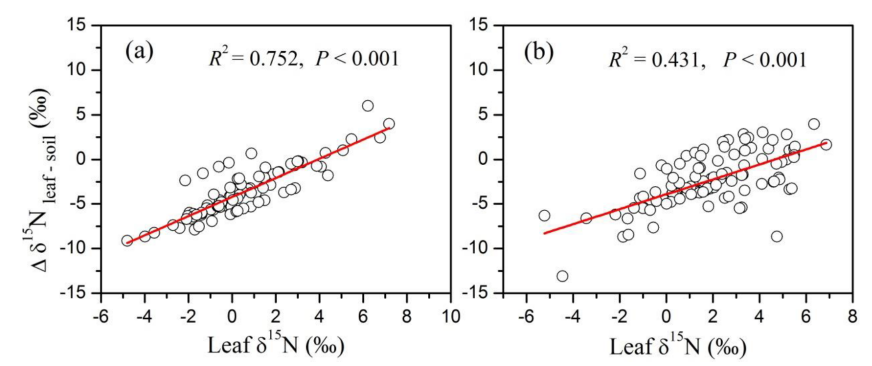

Figure 3. Relationships between $\delta^{15} \mathrm{~N}_{\text {leaf-soil }}$ and leaf $\delta^{15} \mathrm{~N}$ on the north slope (a) and the south slope (b) of Tian Shan.

\section{Results}

\subsection{Comparisons of $\delta^{15} \mathrm{~N}$ in leaf and soil between the north and the south slopes}

In Tian Shan, for all species pooled together, the arithmetic mean (mean $\pm \mathrm{SE}$ ) of leaf $\delta^{15} \mathrm{~N}$ was $0.5 \pm 0.2$ and $2.0 \pm 0.2 \%$ o for the plants grown on the north and south slopes, respectively. One-way ANOVA suggested a significant difference for leaf $\delta^{15} \mathrm{~N}$ between the north and south slopes $(P<0.001$; Fig. $2 \mathrm{a})$. The mean soil $\delta^{15} \mathrm{~N}$ of the north and south slopes was $4.1 \pm 0.4$ and $5.0 \pm 0.8 \%$, respectively. One-way ANOVA showed that the sampled slope exerted no significant effect on soil $\delta^{15} \mathrm{~N}(P=0.290$; Fig. $2 \mathrm{~b})$. The mean $\delta^{15} \mathrm{~N}_{\text {leaf-soil }}$ was $-3.6 \pm 0.3 \%$ for the north slope and $-2.4 \pm 0.3 \%$ o for the south slope, and one-way ANOVA suggested a significant difference in $\delta^{15} \mathrm{~N}_{\text {leaf-soil }}$ between the two slopes $(P=0.003$; Fig. $2 \mathrm{c})$. In addition, this study showed

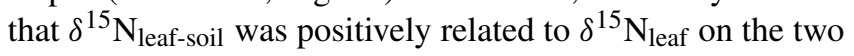
slopes $(P<0.001$; Fig. 3$)$. 


\subsection{The relationships between leaf $\delta^{15} \mathrm{~N}$ and potential influential factors}

A multiple regression of leaf $\delta^{15} \mathrm{~N}$ against potential influential factors including soil $\delta^{15} \mathrm{~N}$, MAT, MAP, leaf $\mathrm{N}$ content, leaf $\mathrm{C} / \mathrm{N}$, soil $\mathrm{N}$ content, soil moisture, soil $\mathrm{pH}$, soil bulk density and silt / clay was conducted. The statistical analyses showed that 45.8 and $23.4 \%$ of the variability in leaf $\delta^{15} \mathrm{~N}$ on the north slope and south slope could be explained as a linear combination of all 10 independent variables, respectively ( $P<0.001$ for the north slope and $P=0.005$ for the south slope; Table 2). Among these influential factors, MAT and leaf $\mathrm{N}$ content correlated positively and leaf C / N, MAP, soil moisture and the silt / clay ratio correlated negatively with leaf $\delta^{15} \mathrm{~N}$ on the north slope (Table 3). The results of PCA also showed that leaf $\mathrm{N}$ content had strong positive effects while leaf $\mathrm{C} / \mathrm{N}$ had negative effects on leaf $\delta^{15} \mathrm{~N}$. MAT and MAP also exerted influences on leaf $\delta^{15} \mathrm{~N}$; however, soil factors almost did not affect leaf $\delta^{15} \mathrm{~N}$ except for silt / clay ratio and soil moisture (Fig. 4a). Whereas on the south slope, only leaf $\mathrm{C} / \mathrm{N}$ was found to have a negative effect on leaf $\delta^{15} \mathrm{~N}$, MAP correlated marginally and negatively with leaf $\delta^{15} \mathrm{~N}$ (Table 4). In addition, on the south slope, principal component 1 (PC1) and principal component 2 (PC2) could almost represent soil conditions and plant traits, respectively; leaf $\delta^{15} \mathrm{~N}$ was affected strongly by leaf $\mathrm{C} / \mathrm{N}$ (Fig. 4b).

\subsection{The relationships between soil $\delta^{15} \mathrm{~N}$ and potential influential factors}

Multiple regression analysis with soil $\delta^{15} \mathrm{~N}$ as a dependent variable and MAT, MAP, soil N content, silt / clay ratio, soil moisture, soil bulk density and soil $\mathrm{pH}$ as independent variables was conducted separately for the north slope and south slope. The statistical analyses showed that the regressions were very significant on both slopes $(P<0.001$ for the both slopes). The seven factors in total accounted for 55.2 and $72.7 \%$ of soil $\delta^{15} \mathrm{~N}$ variance on the north and south slopes, respectively (Table 2). Considering the potential link between soil $\mathrm{N}$ and plant $\mathrm{N}$, new multiple regressions including leaf $\delta^{15} \mathrm{~N}$, leaf $\mathrm{N}$ and leaf $\mathrm{C} / \mathrm{N}$ were performed on the two slopes. Compared to the old multiple regressions, the new regressions did not exhibit changes in $R^{2}$ and $P$ values on both slopes (in the new regressions $P<0.001$ and $R^{2}=0.563$ for the north slope, while $P<0.001$ and $R^{2}=0.738$ for the south slope). Furthermore, compared to the adjusted $R^{2}$ values derived from the old regressions (adjusted $R^{2}=0.513$ for the north slope; adjusted $R^{2}=0.708$ for the south slope), the values of the new regressions were smaller or almost unchanged (adjusted $R^{2}=0.506$ for the north slope; adjusted $R^{2}=0.709$ for the south slope; Table 2). Thus, the new multiple regressions indicated no effect of leaf nutrient traits on soil $\delta^{15} \mathrm{~N}$. Among these factors, MAT, MAP, soil moisture and silt / clay were found to be significantly related to the soil $\delta^{15} \mathrm{~N}$ of the north slope (Table 3). The PCA showed that both MAT and MAP had large loadings on soil $\delta^{15} \mathrm{~N}$. Meanwhile, soil $\delta^{15} \mathrm{~N}$ increased with a decreasing silt / clay ratio and increasing soil moisture (Fig. 4a). However, on the south slope, only MAP and soil moisture were found to play a significant and negative role in soil $\delta^{15} \mathrm{~N}$ (Table 4, Fig. 4b).

\section{Discussion}

\subsection{Differences in leaf $\delta^{15} N$, soil $\delta^{15} N$ and $\delta^{15} N_{\text {leaf-soil }}$ between the south and the north slopes}

In Tian Shan, leaf $\delta^{15} \mathrm{~N}$ and $\delta^{15} \mathrm{~N}_{\text {leaf-soil }}$ both showed higher values on the south slope than the north slope; soil $\delta^{15} \mathrm{~N}$ of the south slope was also more positive than that of the north slope, although the difference was not significant. The results confirmed our hypothesis that, for a given mountain, the leaf $\delta^{15} \mathrm{~N}$, soil $\delta^{15} \mathrm{~N}$ and $\delta^{15} \mathrm{~N}_{\text {leaf-soil }}$ of the south slope could differ from those of the north slope. Greater leaf $\delta^{15} \mathrm{~N}$ on the south slope than north slope suggested that the south slope had higher soil $\mathrm{N}$ availability and higher soil $\mathrm{N}$ transformation rates ( $\mathrm{N}$ mineralization or nitrification rates) (Garten and Van Miegroet, 1994; McLauchlan et al., 2007). Increasing soil $\mathrm{N}$ transformation rates led to an increase in soil available $\mathrm{N}$. Meanwhile, increasing soil $\mathrm{N}$ transformation rates could result in more ${ }^{15} \mathrm{~N}$ enrichment in soil available $\mathrm{N}$ sources. Consequently, plant $\delta^{15} \mathrm{~N}$ increased because $\mathrm{N}$ transformation processes discriminate against ${ }^{14} \mathrm{~N}$.

$\delta^{15} \mathrm{~N}_{\text {leaf-soil }}$ was greater on the south slope than the north slope. This result also suggested that the south slope has higher $\mathrm{N}$ availability and $\mathrm{N}$ mineralization or nitrification rates relative to the north slope because previous studies reported that $\delta^{15} \mathrm{~N}_{\text {leaf-soil }}$ increased with increasing soil $\mathrm{N}$ transformation rates ( $\mathrm{N}$ mineralization or nitrification rates) and N availability (Garten and Van Miegroet, 1994; Kahmen et al., 2008; Cheng et al., 2010).

Amundson et al. (2003) suggested that $\delta^{15} \mathrm{~N}_{\text {leaf-soil }}$ could be interpreted as the isotopic composition of plant-available $\mathrm{N}$ provided that isotopic discrimination does not occur during plant uptake and assimilation. In the present study, we found a highly correlation between leaf $\delta^{15} \mathrm{~N}$ and $\delta^{15} \mathrm{~N}_{\text {leaf-soil }}$ on each slope, which was consistent with the result observed by Craine et al. (2009). Additionally, leaf $\delta^{15} \mathrm{~N}$ has been widely considered as a good approximation for $\delta^{15} \mathrm{~N}$ of soil available nitrogen sources in natural ecosystems (Virginia and Delwiche, 1982; Cheng et al., 2010; Craine et al., 2015a) because $\mathrm{N}$ isotopic discrimination would be negligible during nitrogen uptake and assimilation due to limited soil available $\mathrm{N}$ in most natural ecosystems (Högberg et al., 1999). Thus, the significant correlated relationship between leaf $\delta^{15} \mathrm{~N}$ and $\delta^{15} \mathrm{~N}_{\text {leaf-soil }}$ could provide powerful support for the suggestion in Amundson et al. (2003). 
Table 2. Multiple linear regressions of leaf $\delta^{15} \mathrm{~N}$ and soil $\delta^{15} \mathrm{~N}$ based on ordinary least-square (OLS) estimation.

\begin{tabular}{|c|c|c|c|c|c|c|c|}
\hline \multirow[t]{2}{*}{ Model } & \multirow{2}{*}{$\begin{array}{l}\text { Dependent } \\
\text { variable }\end{array}$} & \multicolumn{3}{|c|}{ North slope } & \multicolumn{3}{|c|}{ South slope } \\
\hline & & $R^{2}$ & Adjusted $R^{2}$ & $P$ & $R^{2}$ & Adjusted $R^{2}$ & $P$ \\
\hline 1 & Leaf $\delta^{15} \mathrm{~N}$ & 0.458 & 0.388 & $<0.001$ & 0.234 & 0.150 & 0.005 \\
\hline 2 & Soil $\delta^{15} \mathrm{~N}$ & 0.552 & 0.513 & $<0.001$ & 0.727 & 0.708 & $<0.001$ \\
\hline 3 & Soil $\delta^{15} \mathrm{~N}$ & 0.563 & 0.506 & $<0.001$ & 0.738 & 0.709 & $<0.001$ \\
\hline
\end{tabular}

Note: In the first model, independent variables were MAT, MAP, leaf N content, leaf C / N, soil $\delta^{15} \mathrm{~N}$, soil N content, silt / clay, soil moisture, soil bulk density and soil $\mathrm{pH}$. In the second model, independent variables were MAT, MAP, soil N content, silt / clay, soil moisture, soil bulk density and soil $\mathrm{pH}$. In the third model, in addition to all the variables in the second model, leaf $\delta^{15} \mathrm{~N}$, leaf $\mathrm{N}$ content and leaf $\mathrm{C} / \mathrm{N}$ were also included in the independent variables.
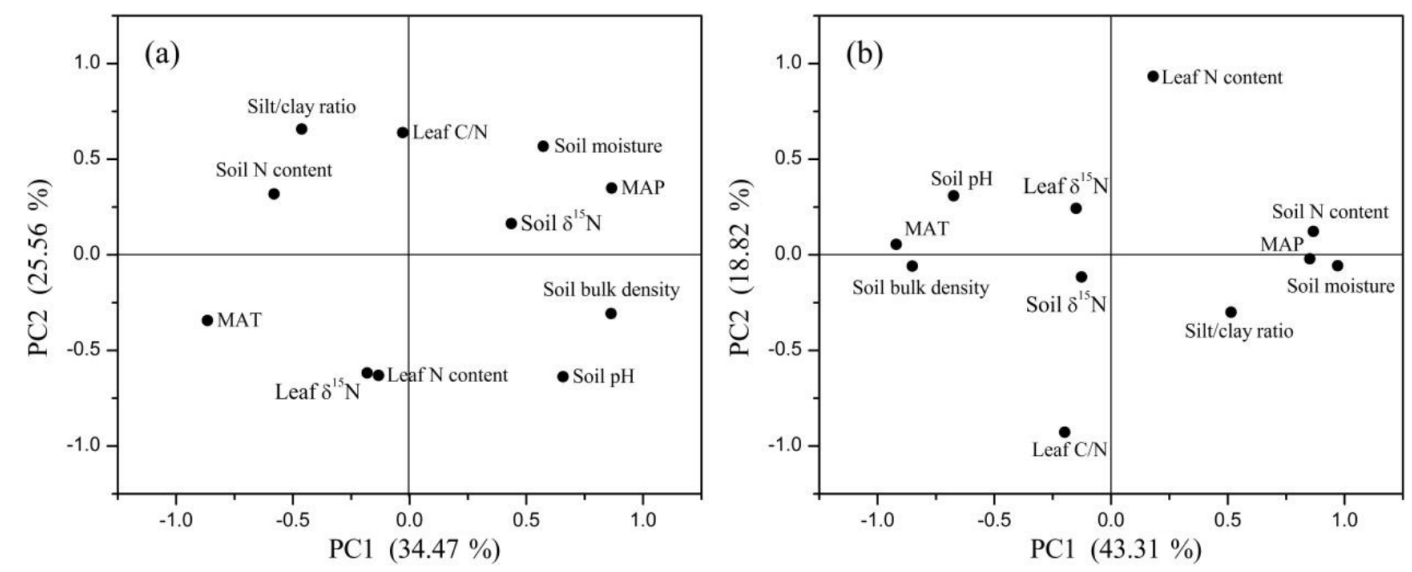

Figure 4. Variable loading on the first two principle components of the north (a) and south slopes (b) of Tian Shan.

Table 3. Correlation analyses between leaf or soil $\delta^{15} \mathrm{~N}$ and influential factors on the north slope of Tian Shan.

\begin{tabular}{lrrrrr}
\hline & \multicolumn{2}{c}{ Leaf $\delta^{15} \mathrm{~N}$} & & \multicolumn{2}{c}{ Soil $\delta^{15} \mathrm{~N}$} \\
\cline { 2 - 3 } \cline { 5 - 6 } & $r$ & $P$ & & $r$ & $P$ \\
\hline Leaf $\delta^{15} \mathrm{~N}$ & 1 & - & & -0.120 & 0.264 \\
Soil $\delta^{15} \mathrm{~N}$ & -0.120 & 0.264 & & 1 & - \\
MAT & $\mathbf{0 . 2 6 6}$ & 0.012 & & $\mathbf{- 0 . 3 8 5}$ & $<0.001$ \\
MAP & $\mathbf{- 0 . 2 7 2}$ & 0.010 & & $\mathbf{0 . 3 8 7}$ & $<0.001$ \\
Leaf N content & $\mathbf{0 . 3 4 0}$ & 0.001 & & -0.090 & 0.397 \\
Leaf C / N & $\mathbf{- 0 . 4 5 2}$ & $<0.001$ & & -0.036 & 0.739 \\
Soil N content & -0.048 & 0.659 & & 0.088 & 0.408 \\
Soil moisture & $-\mathbf{0 . 2 7 1}$ & 0.011 & & $\mathbf{0 . 3 8 8}$ & 0.000 \\
Soil pH & 0.162 & 0.132 & & 0.070 & 0.513 \\
Soil bulk density & -0.056 & 0.604 & & 0.145 & 0.174 \\
Silt / clay ratio & $-\mathbf{0 . 2 3 6}$ & 0.027 & & $\mathbf{- 0 . 3 7 0}$ & $<0.001$ \\
\hline
\end{tabular}

Note: the $r$ values are in bold when $P<0.05$.

\subsection{Influences of various factors on leaf $\delta^{15} \mathrm{~N}$ and soil $\delta^{15} \mathrm{~N}$ : south slope versus north slope}

The regression and correlation analyses showed that each factor did not exert a completely identical effect on leaf $\delta^{15} \mathrm{~N}$ and soil $\delta^{15} \mathrm{~N}$ across the two slopes. This provided powerful
Table 4. Correlation analyses between leaf or soil $\delta^{15} \mathrm{~N}$ and influential factors on the south slope of Tian Shan.

\begin{tabular}{lrrrrr}
\hline & \multicolumn{2}{c}{ Leaf $\delta^{15} \mathrm{~N}$} & & \multicolumn{2}{c}{ Soil $\delta^{15} \mathrm{~N}$} \\
\cline { 2 - 3 } \cline { 5 - 6 } & $r$ & $P$ & & $r$ & $P$ \\
\hline Leaf $\delta^{15} \mathrm{~N}$ & 1 & - & & 0.175 & 0.074 \\
Soil $\delta^{15} \mathrm{~N}$ & 0.175 & 0.074 & & 1 & - \\
MAT & 0.157 & 0.109 & & 0.115 & 0.244 \\
MAP & -0.168 & 0.087 & & $-\mathbf{0 . 2 0 3}$ & 0.038 \\
Leaf N content & 0.119 & 0.229 & & -0.073 & 0.459 \\
Leaf C / N & $-\mathbf{0 . 2 2 8}$ & 0.021 & & 0.062 & 0.533 \\
Soil N content & -0.173 & 0.078 & & 0.014 & 0.888 \\
Soil moisture & -0.141 & 0.150 & & $-\mathbf{0 . 2 2 9}$ & 0.019 \\
Soil pH & 0.04 & 0.686 & & -0.138 & 0.161 \\
Soil bulk density & 0.151 & 0.125 & & 0.041 & 0.679 \\
Silt / clay ratio & -0.07 & 0.477 & & -0.004 & 0.964 \\
\hline
\end{tabular}

Note: the $r$ values are in bold when $P<0.05$.

support for our argument that the influences of environmental factors on leaf $\delta^{15} \mathrm{~N}$ and soil $\delta^{15} \mathrm{~N}$ are localized.

Leaf $\mathrm{C} / \mathrm{N}$ may play a role in regulating biogeochemical cycles of carbon and nitrogen in natural ecosystems (Luo et al., 2004), or, conversely, soil biogeochemistry and plant 
physiology may also cause the shifts in leaf $\mathrm{C} / \mathrm{N}$ stoichiometric characters (Reich and Oleksyn, 2004; Yang et al., 2011). In this study, leaf $\mathrm{C} / \mathrm{N}$ was negatively correlated with leaf $\delta^{15} \mathrm{~N}$ on both slopes of Tian Shan. The result was similar to the finding by Pardo et al. (2006), in which leaf $\delta^{15} \mathrm{~N}$ and root $\delta^{15} \mathrm{~N}$ both decreased with forest floor C / N. A negative correlation between leaf $\mathrm{C} / \mathrm{N}$ and $\delta^{15} \mathrm{~N}$ was also reported for the fine roots in Glacier Bay (Hobbie et al., 2000). Two possible reasons could be responsible for the pattern observed in the present study. First, the increase in leaf C / N might be caused by enhanced photosynthesis, which would aggravate the limit in nitrogen nutrients and result in a decrease in nitrogen availability. As we all know, when soil N availability is high and $\mathrm{N}$ nutrient is rich, soil $\mathrm{N}$ transformations, such as $\mathrm{NH}_{3}$ volatilization and $\mathrm{NO}_{x}$ emissions are enhanced. Consequently, more ${ }^{14} \mathrm{~N}$ losses from soil occur. This causes ${ }^{15} \mathrm{~N}$ enrichment in soil and, subsequently, plant $\delta^{15} \mathrm{~N}$ is more positive. Conversely, plants have more negative $\delta^{15} \mathrm{~N}$ values when soil $\mathrm{N}$ is limited because of weak soil $\mathrm{N}$ transformations and less ${ }^{14} \mathrm{~N}$ loss. Thus, an increase in leaf $\mathrm{C} / \mathrm{N}$ caused a decrease in nitrogen availability and ${ }^{15} \mathrm{~N}$ depletion in plants. Second, leaf C / N was usually considered negatively correlated with leaf $\mathrm{N}$ contents because leaf $\mathrm{C}$ contents always stay relatively stable (Tan and Wang, 2016). The relative stability of leaf $\mathrm{C}$ was also observed in this study. The negative relationship between leaf C / N and leaf $\delta^{15} \mathrm{~N}$ might be caused by the positive relationship between leaf $\mathrm{N}$ content and leaf $\delta^{15} \mathrm{~N}$, which has been reported by many studies (Chen et al., 2015; Zhang et al., 2015; Craine et al., 2009, 2012; Pardo et al., 2006; Martinelli et al., 1999). This study also found a positive relationship between leaf $\mathrm{N}$ content and leaf $\delta^{15} \mathrm{~N}$ on the north slope of Tian Shan.

MAP was observed to be significantly and negatively correlated with leaf $\delta^{15} \mathrm{~N}$ on the north slope; however, on the south slope the relationship was just marginally significant. A negative relationship between leaf $\delta^{15} \mathrm{~N}$ and MAP was reported in many previous studies (Austin and Sala, 1999; Handley et al., 1999; Robinson, 2001; Amundson et al., 2003; Craine et al., 2009). The decrease in leaf $\delta^{15} \mathrm{~N}$ with increasing precipitation could be associated with decreased gaseous $\mathrm{N}$ loss in wetter regions (Houlton et al., 2006).

MAT played a positive role in the leaf $\delta^{15} \mathrm{~N}$ of the north slope, which was consistent with many previous studies (Amundson et al., 2003; Craine et al., 2009); whereas, on the south slope the effect of MAT was not observed. The probable explanation for the observations was that climate on the north slope is very cold (the average MAT $=-1.85^{\circ}$ ) temperature is the key growth-limiting factor for plants. Previous studies consistently suggested that the key factor limiting plant growth generally also plays a dominant role in plant isotope discrimination (McCarroll and Loader, 2004; Winter et al., 1982; Xu et al., 2015); thus, temperature exerted an effect on leaf $\delta^{15} \mathrm{~N}$. However, on the south slope, climate is relatively warm, except for those sites with higher altitudes, and usually temperature does not limit plant growth. Thus, leaf $\delta^{15} \mathrm{~N}$ was not related to temperature. With respect to the positive effect of temperature on the north slope, the mechanism might be that higher temperatures favor more complete plant nitrogen assimilation and transformation, which might decrease isotopic fractionation during $\mathrm{N}$ assimilation and transformation, then causing ${ }^{15} \mathrm{~N}$ enrichment in plants.

In Tian Shan, soil $\delta^{15} \mathrm{~N}$ increased with increasing MAP on the north slope, while it decreased with increasing MAP on the south slope. Soil $\delta^{15} \mathrm{~N}$ could be determined by the balance of the $\mathrm{N}$ input or output processes and corresponding isotopic fractionation factors (Brenner et al., 2001; Bai and Houlton, 2009; Wang et al., 2014). Considering that the leaching loss could be neglected on both slopes because of the dry environment, soil $\delta^{15} \mathrm{~N}$ can be estimated with the following equation:

soil $\delta^{15} \mathrm{~N}=\delta^{15} \mathrm{~N}_{\text {input }}+\varepsilon_{\mathrm{G}} \times f_{\mathrm{G}}+\varepsilon_{\mathrm{P}} \times f_{\mathrm{P}}$,

where $\delta^{15} \mathrm{~N}_{\text {input }}$ is the input of $\delta^{15} \mathrm{~N} ; f_{\mathrm{G}}$ and $f_{\mathrm{P}}$ are the fraction of gas losses and net plant $\mathrm{N}$ accumulation out of total $\mathrm{N}$ losses (\%), respectively; and $\varepsilon_{\mathrm{G}}$ and $\varepsilon_{\mathrm{P}}$ are the fractionation factors of corresponding $\mathrm{N}$ losses processes.

$f_{\mathrm{G}}+f_{\mathrm{P}}=1$

$\varepsilon_{\mathrm{G}}$ varies from 16 to $30 \%$ (Handley et al., 1999; Robinson, 2001); and $\varepsilon_{\mathrm{P}}$ is between 5 and $10 \%$ (Handley et al., 1999; Evans, 2001). Thus, in general, $\varepsilon_{\mathrm{G}}>\varepsilon_{\mathrm{P}}$, and soil $\delta^{15} \mathrm{~N}$ is correlated positively with $f_{\mathrm{G}}$ and negatively with $f_{\mathrm{P}}$ based on Eqs. (1) and (2). On the north slope, rainfall events may accelerate the gas losses (nitrification and denitrification processes) more than plant $\mathrm{N}$ uptake, while this may be opposite on the south slope. On the north slope, with an increase in MAP, $f_{\mathrm{G}}$ increases and causes ${ }^{15} \mathrm{~N}$ enrichment in soil; on the south slope, $f_{\mathrm{P}}$ increases with MAP and results in ${ }^{15} \mathrm{~N}$ depletion in soil.

The effects of the silt / clay ratio on soil $\delta^{15} \mathrm{~N}$ might be driven by the indirect effects of the silt / clay ratio on soil moisture and soil oxygen concentrations. The north slope is wetter than the south slope, and the north slope shows more denitrification, while nitrification is more prevalent on the south slope. On the north slope, with an increase in the silt / clay ratio, soil oxygen concentration increases and this inhibits soil denitrification. Consequently, ${ }^{15} \mathrm{~N}$ depletion in soil would occur; thus, the silt / clay ratio showed a negative relationship with soil $\delta^{15} \mathrm{~N}$.

\section{Conclusions}

We sampled plants and soils on the south slope and north slope of Tian Shan and measured their $\delta^{15} \mathrm{~N}$. The south slope differs significantly in climate and environment from the north slope. In the present study, leaf $\delta^{15} \mathrm{~N}$ and $\delta^{15} \mathrm{~N}_{\text {leaf-soil }}$ (leaf $\delta^{15} \mathrm{~N}-$ soil $\delta^{15} \mathrm{~N}$ ) of the south slope were more positive than those of the north slope; soil $\delta^{15} \mathrm{~N}$ of the south slope was 
also higher than that of the north slope, although the difference between the two slopes was not significant. The results suggest that the south slope has higher soil $\mathrm{N}$ transformation rates and soil $\mathrm{N}$ availability relative to the north slope. In addition, among the potential influential factors, MAP, leaf $\mathrm{C} / \mathrm{N}$, soil moisture and silt / clay ratio had negative effects while MAT and leaf $\mathrm{N}$ content had positive effects on leaf $\delta^{15} \mathrm{~N}$ of the north slope; however, on the south slope, only leaf C / N played a negative role in leaf $\delta^{15} \mathrm{~N}$. For soil $\delta^{15} \mathrm{~N}$, the significant influential factors were MAT, MAP, soil moisture and silt / clay ratio on the north slope, whereas on the south slope, MAP and soil moisture exerted significant effects. Interestingly, MAP was found to exert contrary effects on soil $\delta^{15} \mathrm{~N}$ between the two slopes. This indicated that environmental influences on leaf $\delta^{15} \mathrm{~N}$ and soil $\delta^{15} \mathrm{~N}$ are localized.

Data availability. There is no underlying material and related items in this paper. All data are provided in the Supplement.

\section{The Supplement related to this article is available online at https://doi.org/10.5194/bg-15-369-2018-supplement.}

Competing interests. The authors declare that they have no conflict of interest.

Acknowledgements. This research was supported by the Chinese National Basic Research Program (no. 2014CB954202) and the National Natural Science Foundation of China (no. 41272193). We would like to thank Ma Yan for analyzing nitrogen isotopes at the Stable Isotope Laboratory of the College of Resources and Environment, China Agricultural University.

Edited by: Sébastien Fontaine

Reviewed by: two anonymous referees

\section{References}

Amundson, R., Austin, A. T., Schuur, E. A. G., Yoo, K., Mztzek, V., Kendall, C., Uebersax, A., Brenner, D., and Baisden, W. T.: Global patterns of the isotopic composition of soil and plant nitrogen, Global Biogeochem. Cy., 17, 1031, https://doi.org/10.1029/2002GB001903, 2003.

Austin, A. T. and Sala, O. E.: Foliar $\delta^{15} \mathrm{~N}$ is negatively correlated with rainfall along the IGBP transect in Australia, Aust. J. Plant Physiol., 26, 293-295, 1999.

Bai, E. and Houlton, B. Z.: Coupled isotopic and processbased modeling of gaseous nitrogen losses from tropical rain forests, Global Biogeochem. Cy., 23, GB2011, https://doi.org/10.1029/2008GB003361, 2009.
Brenner, D. L., Amundson, R., Baisden, W. T., Kendall, C., and Harden, J.: Soil $\mathrm{N}$ and ${ }^{15} \mathrm{~N}$ variation with time in a California annual grassland ecosystem, Geochim. Cosmochim. Ac., 65, 41714186, 2001.

Charles, T. and Garten, J. R.: Variation in foliar ${ }^{15} \mathrm{~N}$ abundance and the availability of soil nitrogen on Walker Branch Watershed, Ecology, 74, 2098-2113, 1993.

Chen, L. T., Flynn, D. F. B., Zhang, X. W., Gao, X. L., Lin, L., Luo, J., and Zhao, C. M.: Divergent patterns of foliar $\delta^{13} \mathrm{C}$ and $\delta^{15} \mathrm{~N}$ in Quercus aquifolioides with an altitudinal transect on the Tibetan Plateau: an integrated study based on multiple key leaf functional traits, J. Plant Ecol., 8, 303-312, 2015.

Cheng, S. L., Fang, H. J., Yu, G. R., Zhu, T. H., and Zheng, J. J.: Foliar and soil ${ }^{15} \mathrm{~N}$ natural abundances provide field evidence on nitrogen dynamics in temperate and boreal forest ecosystems, Plant Soil, 337, 285-297, 2010.

Cheng, W. X., Chen, Q. S., Xu, Y. Q., Han, X. G., and Li, L. H.: Climate and ecosystem ${ }^{15} \mathrm{~N}$ natural abundance along a transect of Inner Mongolian grasslands: Contrasting regional patterns and global patterns, Global Biogeochem. Cy., 23, GB2005, https://doi.org/10.1029/2008GB003315, 2009.

Craine, J. M., Elmore, A. J., Aidar, M. P. M., Bustamante, M., Dawson, T. E., Hobbie, E. A., Kahmen, A., Mack, M. C., McLauchlan, K. K., Michelsen, A., Nardoto, G. B., Pardo, L. H., Peñuelas, J., Reich, P. B., Schuur, E. A. G., Stock, W. D., Templer, P. H., Virginia, R. A., Welker, J. M., and Wright, I. J.: Global patterns of foliar nitrogen isotopes and their relationships with climate, mycorrhizal fungi, foliar nutrient concentrations, and nitrogen availability, New Phytol., 183, 980-992, 2009.

Craine, J. M., Gene Towne, E., Ocheltree, T. W., and Nippert, J. B.: Community traitscape of foliar nitrogen isotopes reveals $\mathrm{N}$ availability patterns in a tallgrass prairie, Plant Soil, 356, 395403, 2012.

Craine, J. M., Brookshire, E. N. J., Cramer, M. D., Hasselquist, N. J., Koba, K., Marin-Spiotta, E., and Wang, L. X.: Ecological interpretations of nitrogen isotope ratios of terrestrial plants and soils, Plant Soil, 396, 1-26, 2015 a.

Craine, J. M., Elmore, A. J., Wang, L. X., Augusto, L., Baisden, W. T., Brookshire, E. N. J., Cramer, M. D., Hasselquist, N. J., Hobbie, E. A., Kahmen, A., Koba, K., Kranabetter, J. M., Mack, M. C., Marin-Spiotta, E., Mayor, J. R., McLauchlan, K. K., Michelsen, A., Nardoto, G. B., Oliveira, R. S., Perakis, S. S., Peri, P. L., Quesada, C. A., Richter, A., Schipper, L. A., Stevenson, B. A., Turner, B. L., Viani, R. A. G., Wanek, W., and Zeller, B.: Convergence of soil nitrogen isotopes across global climate gradients, Sci. Rep., 5, 8280, https://doi.org/10.1038/srep08280, 2015b.

Deng, H. J., Chen, Y. N., Wang, H. J., and Zhang, S. H.: Climate change with elevation and its potential impact on water resources in the Tianshan Mountains, Central Asia, Global Planet. Change, 135, 28-37, 2015.

Emmett, B. A., Kjønaas, O. J., Gundersen, P., Koopmans, C., Tietema, A., and Sleep, D.: Natural abundance of ${ }^{15} \mathrm{~N}$ in forest across a nitrogen deposition gradient, Forest Ecol. Manag., 101, 9-18, 1998.

Evans, R. D.: Physiological mechanisms influencing plant nitrogen isotope composition, Trends Plant Sci., 6, 121-126, 2001.

Fang, H. J., Yu, G. R., Cheng, S. L., Zhu, T. H., Zheng, J. J., Mo, J. M., Yan, J. H., and Luo, Y. Q.: Nitrogen-15 signals of leaf-litter- 
soil continuum as a possible indicator of ecosystem nitrogen saturation by forest succession and N loads, Biogeochemistry, 102, 251-263, 2011.

Garten, C. T. J. and Van Miegroet, H.: Relationships between soil nitrogen dynamics and natural ${ }^{15} \mathrm{~N}$ abundance in plant foliage from Great Smoky Mountains National Park, Can. J. Forest Res., 24, 1636-1645, 1994.

Handley, L. L., Austin, A. T., Robinson, D., Scrimgeour, C. M., Raven, J. A., Heaton, T. H. E., Schmidt, S., and Stewart, G. R.: The ${ }^{15} \mathrm{~N}$ natural abundance $\left(\delta^{15} \mathrm{~N}\right)$ of ecosystem samples reflects measures of water availability, Aust. J. Plant Physiol., 26, 185199, 1999.

Hobbie, E. A. and Colpaert, J. V.: Nitrogen availability and colonization by mycorrhizal fungi correlate with nitrogen isotope patterns in plants, New Phytol., 157, 115-126, 2003.

Hobbie, E. A., Macko, S. A., and Williams, M.: Correlations between foliar $\delta^{15} \mathrm{~N}$ and nitrogen concentrations may indicate plant-mycorrhizal interactions, Oecologia, 122, 273-283, 2000.

Högberg, P.: ${ }^{15} \mathrm{~N}$ natural abundance in soil-plant systems, New Phytol., 137, 179-203, 1997.

Högberg, P., Högberg, M. N., Quist, M. E., Ekblad, A., and Näsholm, T.: Nitrogen isotope fractionation during nitrogen uptake by ectomycorrhizal and non-mycorrhizal Pinus sylvestris, New Phytol., 142, 569-576, 1999.

Houlton, B. Z., Sigman, D. M., and Hedin, L. O.: Isotopic evidence for large gaseous nitrogen losses from tropical rainforest, P. Natl. Acad. Sci. USA, 103, 8745-8750, 2006.

Houlton, B. Z., Sigman, D. M., Schuur, E. A. G., and Hedin, L. O.: A climate driven switch in plant nitrogen acquisition within tropical forest communities, P. Natl. Acad. Sci. USA, 104, 89028906, 2007.

Kahmen, A., Wanek, W., and Buchmann, N.: Foliar $\delta^{15} \mathrm{~N}$ values characterize soil $\mathrm{N}$ cycling and reflect nitrate or ammonium preference of plants along a temperate grassland gradient, Oecologia, 156, 861-870, 2008.

Luo, Y. Q., Su, B., Currie, W. S., Dukes, J. S., Finzi, A., Hartwig, U., Hungate, B., McMurtrie, R. E., Oren, R., Parton, W. J., Pataki, D. E., Shaw, M. R., Zak, D. R., and Field, C. B.: Progressive nitrogen limitation of ecosystem responses to rising atmospheric carbon dioxide, Bioscience, 54, 731-739, 2004.

Martinelli, L., Piccolo, M. C., Townsend, A. R., Vitousek, P. M., Cuevas, E., McDowell, W., Robertson, G. P., Santos, O. C., and Treseder, K.: Nitrogen stable isotope composition of leaves and soils: tropical versus temperature forest, Biogeochemistry, 46, 45-65, 1999.

McCarroll, D. and Loader, N.: Stable isotopes in tree rings, Quaternary Sci. Rev., 23, 771-801, https://doi.org/10.1016/j.quascirev.2003.06.017, 2004.

McLauchlan, K. K., Craine, J. M., Oswald, W. W., and Likens, G. E.: Changes in nitrogen cycling during the past century in a northern hardwood forest, P. Natl. Acad. Sci. USA, 104, 74667470, 2007.

Pardo, L. H., Templer, P. H., Goodale, C. L., Duke, S., Groffman, P. M., Adams, M. B., Boeckx, P., Boggs, J., Campbell, J., Colman, B., Compton, J., Emmett, B., Gundersen, P., Kjønaas, J., Lovett, G., Mack, M., Magill, A., Mbila, M., Mitchell, M. J., McGee, G., McNulty, S., Nadelhoffer, K., Ollinger, S., Ross, D., Rueth, H., Rustad, L., Schaberg, P., Schiff, S., Schleppi, P., Spoelstra, J., and Wessel, W.: Regional assessment of $\mathrm{N}$ saturation using foliar and $\operatorname{root} \delta^{15} \mathrm{~N}$, Biogeochemistry, 80, 143-171, 2006.

Reich, P. B. and Oleksyn, J.: Global patterns of plant leaf N and P in relation to temperature and latitude, P. Natl. Acad. Sci. USA, 101, 11001-11006, 2004.

Robinson, D.: $\delta^{15} \mathrm{~N}$ as an integrator of the nitrogen cycle, Trends Ecol. Evol., 16, 153-162, 2001

Sheng, W. P., Yu, G. R., Fang, H. J., Liu, Y. C., Wang, Q. F., Chen, Z. F., and Zhang, L.: Regional patterns of ${ }^{15} \mathrm{~N}$ natural abundance in forest ecosystems along a large transect in eastern China, Sci. Rep., 4, 4249, https://doi.org/10.1038/srep04249, 2014.

Tan, Q. Q. and Wang, G. A.: Decoupling of nutrients element cycles of soil and plants across an altitude gradient, Sci. Rep., 6, 34875, https://doi.org/10.1038/srep34875, 2016.

Virginia, R. A. and Delwiche, C. C.: Natural ${ }^{15} \mathrm{~N}$ abundance of presumed $\mathrm{N}_{2}$-fixing and non- $\mathrm{N}_{2}$-fixing plants from selected ecosystems, Oecologia, 54, 317-325, 1982.

Vitousek, P. M., Aber, J. D., Howarth, R. W., Likens, G. E., Matson, P. A., Schindler, D. W., Schlesinger, W. H., and Tilman, D. G.: Human alteration of the global nitrogen cycle: source and consequences, Ecol. Appl., 7, 737-750, 1997.

Wang, C., Wang, X. B., Liu, D. W., Wu, H. H., Lü, X. T., Fang, Y. T., Cheng, W. X., Luo, W. T., Jiang, P., Shi, J., Yin, H. Q., Zhou, J. Z., Han, X. G., and Bai, E.: Aridity threshold in controlling ecosystem nitrogen cycling in arid and semi-arid grasslands, Nat. Commun., 5, 4799, https://doi.org/10.1038/ncomms5799, 2014.

Winter, K., Holtum, J. A. M., Edwards, G. E., and O'Leary, M. H.: Effect of low relative humidity on $\delta^{13} \mathrm{C}$ value in two $\mathrm{C}_{3}$ grasses and in Panicum milioides, $\mathrm{a} \mathrm{C}_{3}-\mathrm{C}_{4}$ intermediate species, J. Exp. Bot., 33, 88-91, https://doi.org/10.1093/jxb/33.1.88, 1982.

Xu, M., Wang, G. A., Li, X. L., Cai, X. B., Li, X. L., Christie, P., and Zhang, J. L.: The key factor limiting plant growth in cold and humid alpine areas also plays a dominant role in plant carbon isotope discrimination, Front. Plant Sci., 6, 961, https://doi.org/10.3389/fpls.2015.00961, 2015.

Yang, Y. H., Luo, Y. Q., Lu, M., Schädel, C., and Han, W. X.: Terrestrial $\mathrm{C}: \mathrm{N}$ stoichiometry in response to elevated $\mathrm{CO}_{2}$ and $\mathrm{N}$ addition: a synthesis of two meta-analyses, Plant Soil, 343, 393400, 2011.

Yang, Y. H., Ji, C. J., Robinson, D., Zhu, B., Fang, H. J., Shen, H. H., and Fang, J. Y.: Vegetation and soil ${ }^{15} \mathrm{~N}$ natural abundance in alpine grassland on the Tibetan Plateau: patterns and implications, Ecosystems, 16, 1013-1024, 2013.

Zhang, J., Gu, L., Zhang, J., Wu, R., Wang, F., Lin, G., Wu, B., Lu, Q., and Meng, P.: The interaction between nitrogen and phosphorous is a strong predictor of intra-plant variation in nitrogen isotope composition in a desert species, Biogeosciences Discuss., https://doi.org/10.5194/bgd-12-18769-2015, 2015.

Zhang, R. B., Yuan, Y. J., Gou, X. H., Zhang, T. W., Zou, C., Ji, C. R., Fan, Z. A., Qin, L., Shang, H. M., and Li, X. J.: Intra-annual radial growth of Schrenk spruce (Picea schrenkiana Fisch. Et Mey) and its response to climate on the northern slopes of the Tianshan Mountains, Dendrochronologia, 40, 36-42, 2016.

Zhou, Y. C., Cheng, X. L., Fan, J. W., and Harris, W.: Patterns and controls of foliar nitrogen isotope composition on the QinghaiTibet Plateau, China, Plant Soil, 406, 265-276, 2016. 